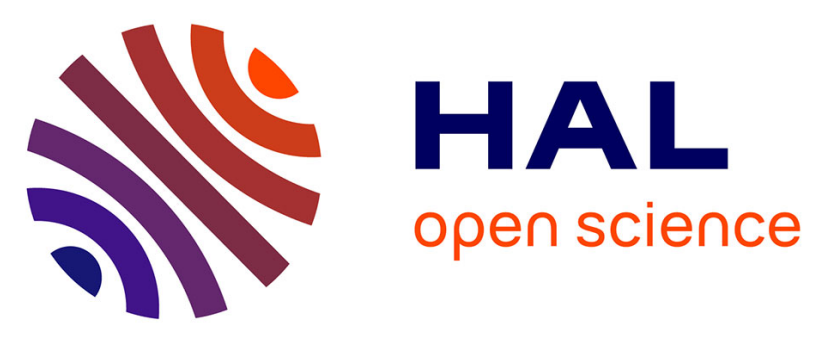

\title{
Impaired Anger Control as an Underappreciated Side Effect of Treatments for Chronic HCV Infection in HIV-HCV Coinfected Patients
}

\author{
Marie Préau, Fabienne Marcellin, Bruno Spire, Isabelle Ravaux, Pierre \\ Dellamonica, Dominique Blanc, Maria Patrizia Carrieri
}

\section{To cite this version:}

Marie Préau, Fabienne Marcellin, Bruno Spire, Isabelle Ravaux, Pierre Dellamonica, et al.. Impaired Anger Control as an Underappreciated Side Effect of Treatments for Chronic HCV Infection in HIV-HCV Coinfected Patients. Journal of Clinical Gastroenterology, 2008, 42, pp.92 - 96. 10.1097/01.mcg.0000225645.75651.b8 . halshs-01563621

\section{HAL Id: halshs-01563621 \\ https://shs.hal.science/halshs-01563621}

Submitted on 17 Jul 2017

HAL is a multi-disciplinary open access archive for the deposit and dissemination of scientific research documents, whether they are published or not. The documents may come from teaching and research institutions in France or abroad, or from public or private research centers.
L'archive ouverte pluridisciplinaire HAL, est destinée au dépôt et à la diffusion de documents scientifiques de niveau recherche, publiés ou non, émanant des établissements d'enseignement et de recherche français ou étrangers, des laboratoires publics ou privés. 


\section{Impaired Anger Control as an}

\section{Underappreciated Side Effect of Treatments for Chronic HCV Infection in HIV-HCV Coinfected...}

Article in Journal of Clinical Gastroenterology · February 2008

DOI: 10.1097/01.mcg.0000225645.75651.b8 · Source: PubMed

CITATIONS

18

7 authors, including:

Marie Préau

Université Lumiere Lyon 2

155 PUBLICATIONS 1,121 CITATIONS

SEE PROFILE

\section{Bruno Spire}

French Institute of Health and Medical Resea..

342 PUBLICATIONS 7,597 CITATIONS

SEE PROFILE
READS

25
Fabienne Marcellin

French Institute of Health and Medical Resea...

70 PUBLICATIONS 825 CITATIONS

SEE PROFILE

\section{Isabelle Ravaux}

Assistance Publique Hôpitaux de Marseille 63 PUBLICATIONS 909 CITATIONS

SEE PROFILE

Some of the authors of this publication are also working on these related projects:

Project
DÉPIST' HSH La question du recours tardif au test de dépistage du VIH Une étude des enjeux psychosociaux à l'œuvre en France chez les HSH. View project

ANRS-QUALIPEP - Qualitative Study on access to PEP in one French region and acceptability of community-based PEP View project 
Impaired anger control as an underappreciated side effect of treatments for chronic HCV infection in HIV-HCV coinfected patients

Marie Préau ${ }^{1,2,3}$ PhD, Fabienne Marcellin ${ }^{1,2}$ Msc, Bruno Spire ${ }^{1,2}$ MD, Isabelle Ravaux ${ }^{4}$, Pierre Dellamonica ${ }^{5}$ MD Pr, Dominique Blanc ${ }^{6}$ MD and Maria Patrizia Carrieri ${ }^{1,2}$ PhD

${ }^{1}$ INSERM research Unit 379 "Epidemiology and Social Sciences applied to medical innovation", Marseilles, France

${ }^{2}$ Southeastern Health Regional Observatory (ORS-PACA), Marseilles, France

${ }^{3}$ Health and Social Psychology Department, Provence University, Aix-Marseilles I - Aix en Provence, France

${ }^{4}$ Conception Hospital, Infectious disease, Marseilles

${ }^{5}$ L'Archet Hospital, Infectious disease, Nice

${ }^{6}$ AIDES/TRT5, Paris

Corresponding author: Marie PRÉAU, INSERM U379/ORS PACA, 23 rue Stanislas Torrents, 13006 Marseille, France. Tel : +33 4961028 80. Fax : +334961028 99. Email :preau@marseille.inserm.fr

Grants : This research was supported by the charity organisation ECS-SIDACTION (France). 


\title{
Impaired anger control as an underappreciated side effect of treatments for chronic HCV infection in HIV-HCV coinfected patients
}

\begin{abstract}
OBJECTIVE: To study the specific impact of treatments for chronic hepatitis $\mathrm{C}$ virus (HCV) infection on anger expression and control in adult patients coinfected with HIV and HCV receiving antiretroviral therapy.

DESIGN: In 2005, a cross-sectional survey, collecting both clinical and sociobehavioral data, was conducted in two French clinical centers among adult patients coinfected with HIV and HCV.

METHODS: Participants were asked to answer anonymously a self-administered questionnaire aimed at obtaining sociodemographic, clinical and behavioral characteristics including self-reported treatments' side effects, quality of life (WHOQOL-HIV BREF), and irritability and anger (STAXI-2). Clinical characteristics were obtained from medical records. RESULTS: Among the 139 patients who were receiving antiretroviral therapy at the time of survey and who had complete self-reported data, 24 were being treated for their HCV infection, using either pegylated interferon (pegIFN) and ribavirin (RBV) or pegIFN alone. Control of anger was significantly lower among treated patients than among untreated ones (STAXI-2 anger control-out dimension median scores of 18.5 versus 23 respectively, $P=$ 0.02). Sociodemographic and clinical characteristics did not differ significantly between these 2 groups. Control of angry feelings was significantly correlated with psychological and social relationship dimensions of quality of life.
\end{abstract}

CONCLUSION: Treatment of HCV-HIV co-infected patients may require closer monitoring for anger control issues and adjustment of treatment as appropriate. 


\section{Keywords:}

Anger, HIV/HCV coinfection, Interferon, Ribavirin, Quality of life 


\section{Impaired anger control as an underappreciated side effect of treatment(s) for chronic HCV infection in HIV-HCV coinfected patients}

\section{Introduction}

With the dramatic improvement in treating many fatal complications of HIV infection, liver disease as a consequence of viral hepatitis $\mathrm{C}$ has emerged as a major cause of morbidity and mortality $(2,3)$. As an estimated $15-30 \%$ of HIV infected patients are also infected with hepatitis $\mathrm{C}$ virus $(\mathrm{HCV})(4,5), \mathrm{HIV}-\mathrm{HCV}$ coinfection has become a critical issue because of the interactions between the two viruses $(6,7)$ which worsen the clinical course of HCV infection $(8,9)$. Besides, in patients already being treated with antiretrovirals, HCV infection constitutes an additional burden associated with disabling symptoms, such as fatigue, which impair their quality of life (QOL) (10). Pegylated interferon alpha (PegIFN) therapy in combination with ribavirin (RBV) is the most efficient treatment for $\mathrm{HCV}$ infection (11). While anxiety and depression have been extensively described as common side effects of interferon therapy, data on the occurrence and management of other neuropsychiatric disorders such as anger remain scarce (12-15). However, anger has been identified as an independent predictor of progression to AIDS (16) and its prevalence in older HIV-infected patients has been reported (17). In this context, we aimed at investigating the specific impact of treatment for HCV infection on anger expression and control in adult HIV-HCV coinfected patients receiving antiretroviral therapy.

\section{Patients and methods}

In 2005, a cross-sectional survey was conducted among 223 coinfected patients being followed-up in two clinical centers located in the south of France (Nice, Marseilles). Participation in the survey was proposed to all adult HIV-infected patients who were co- 
infected with HCV virus, as documented by a positive HCV RNA detection test. Patients who agreed to participate were presented a self-administered questionnaire which included items on clinical status and history, sociodemographic characteristics and behavioral data, as well as self-reported side effects of antiretrovirals and QOL (WHO QOL-HIV BREF scale (18)). This scale assesses six dimensions of QOL: physical QOL (bodily pain, sleep, tiredness), psychological QOL (satisfaction with cognitive capacity, self-esteem, self-image, positive and negative feelings), environmental QOL (satisfaction with physical security, home, accessibility and quality of health care, information, transport, pollution, noise, spare-time activities), level of independence QOL (mobility, employment), QOL concerning social relationship aspects (interpersonal relationships, social support, sexual activity, social integration in relation to seropositivity) and spirituality. Patients' irritability and anger were evaluated using the French adaptation of the 57-item State-Trait Anger Expression Inventory2 (STAXI-2) of Spielberger (19), which aims at exploring the different facets of anger simultaneously. This psychometric instrument measures the intensity of anger as an emotional state (State Anger, associated score ranging from 15 to 60) and the disposition to experiencing angry feelings as a personality trait (Trait Anger, associated score ranging from 10 to 40). It also contains a subscale evaluating anger expression and control. According to Spielberger's in-depth analyses concerning the factorial structure of the instrument, this subscale can be divided into four distinct dimensions: expressing anger towards other people or objects in the environment (Anger Expression-Out), holding in angry feelings (Anger Expression-In), controlling angry feelings by preventing the expression of anger towards other people or objects in the environment (Anger Control-Out), and controlling angry feelings by calming down or cooling off (Anger Control-In). Because of the correlations between Anger Expression-In and Anger Expression-Out on one part, and between Anger Control-In and Anger Control-Out on the other part, subscale scoring can be done either separately for each 
dimension (scores range: 8 to 32), or using a global anger expression and control score. Higher scores denote more anger.

\section{Statistical methods}

Characteristics of patients being treated for their HCV infection and those who were not were compared using the Wilcoxon rank-sum test (continuous variables) and Fisher's exact test (categorical variables). Correlations between STAXI-2 and QOL dimensions were explored using Pearson's correlation coefficient. Significance level was fixed at $\alpha=0.05$. Analyses were performed using SAS ${ }^{\circledR}$ software version 9.1 for Windows (SAS Institute, Cary, NC, USA)

\section{Results}

A total of 223 patients agreed to participate in the survey, of whom $152(68.2 \%)$ answered the self-administered questionnaire (respondents). Reasons most frequently given for nonresponse were lack of interest, desire or time. Respondents were not significantly different from non-respondents in terms of age, sex, HIV clinical status (HIV viral load, CDC stage C), and fibrosis stage ${ }^{1}$ (results not shown). In order to isolate the specific effect of HCV treatment on patients' irritability and anger, we focused our analysis on patients already being treated for HIV infection at the time of the survey, as they constituted the majority of respondents $(n=139,91.4 \%)$. Characteristics of these patients are presented in Table 1. Most of them were men (64.0\%), mean age (standard deviation) was 42.9 (5.4) years and mean time since HCV diagnosis was 10.9 (5.4) years. Seventy-three percent of patients had contracted HCV infection from IV drug abuse. Forty-eight patients were diagnosed with a fibrosis score

\footnotetext{
${ }^{1}$ data on fibrosis stage (biopsy results or FibroTest ${ }^{\mathrm{TM}}$ score) were available for half of the patients
} 
exceeding F2 (METAVIR) and were therefore treated according to the existing recommendations for $\mathrm{HCV}$ treatment. Twenty-four patients were being treated for $\mathrm{HCV}$ infection at the time of survey, mainly using a combination therapy of pegIFN and RBV ( $\mathrm{n}=21$ patients) and, to a lesser extent, using pegIFN alone ( $\mathrm{n}=3$ patients). There was no significant difference between patients being treated for $\mathrm{HCV}$ and those who were not with respect to all considered socio-demographic and clinical characteristics, including CES-D global depression score (Table 1). Only one treated patient reported regular alcohol consumption during the previous six months ( $v s 27$ untreated patients, $P=0.05$ ). Patients being treated presented significantly lower STAXI-2 scores for Anger Control-Out than those who were not, with median [interquartile range] scores of respectively $18.5[17.5 ; 23]$ and 23 [18; 26] $(P=0.02)$ (Table 2). Anger Control-Out was positively correlated with three domains of QOL (psychological QOL: $\mathrm{r}=0.42, P<0.0001$; social relationships QOL: $\mathrm{r}=0.26, P=0.01$; environmental QOL: $\mathrm{r}=0.25, P=0.01)$.

\section{Discussion}

The data presented here suggest that anger control out is associated with pegIFN HCV treatment among patients co-infected with HIV. This result is consistent with literature on anger among $\mathrm{HCV}$ mono-infected patients $(13,17,20)$, and provides further information about the association between IFN therapy and neuropsychiatric disorders, as many other studies have focused only on depression. Besides, it underlines the necessity to take into account anger as a characteristic, which can have several implications on the management of HIV and HCV. Indeed, anger has already been shown to be associated with non adherence (21) and depressive symptoms (20) in the context of HCV infection and has also been shown to impact independently on HIV clinical progression (16). Our study identified an association between anger control-out and psychological and environmental aspects of QOL as well as 
social relationships. It can therefore be hypothesized that lack of anger control impairs patients' interactions with their close relations or occupational companions and also with their healthcare providers- interactions which have been shown to be of crucial importance in HIVinfected patients' QOL (22). All of these considerations underline the important role of anger among psychological disorders and difficulties of coinfected patients and highlight the necessity of adequate management of this problem.

It is interesting to note that no difference was detected in our study in terms of depression score between those patients being treated and those not being treated for $\mathrm{HCV}$ infection. As HIV-infected drug users are more likely to present depressive symptoms (23), this result could be attributed to the fact that many of the study's patients may already have presented a depressive symptomatology, as more than $70 \%$ of them were HIV-infected through IDU.

In addition, our results show that anger control is the main characteristic of anger related to QOL and treatment. Again, this may be due to the high prevalence of patients infected through IDU in the study population. Indeed, a previous study indicated that drug users have a high risk of anger (related) hostility symptoms, are more likely to express anger towards other people or objects in the environment, and have less control over their angry feelings (24). Besides, a cross sectional study based on data collected in the pre-HAART era in HIVinfected patients had demonstrated that patients HIV-infected through drug injection report more symptoms and higher overall and physical symptom distress than those belonging to other HIV-transmission categories (25), which can result in exacerbated angry feelings. In addition, these patients may not be adequately treated for their side effects including anger (26). However, we pointed out a significant difference concerning angry feelings between $\mathrm{HCV}$ treated and not treated patients despite well-balanced proportions of former or active drug users in these two groups, which underlines the determinant impact of HCV treatment on anger. 
The failure of the study to find differences on anger dimensions other than control-out between those patients being treated for HCV and those who were not may be due to limited statistical power. Besides, the use of a self-administered questionnaire to address anger issues may be limiting, as it does not take into account perceptions of the patients' environment regarding this problem. Therefore, studies including anger assessment of the patient's environment should be conducted for complementary information. Finally, studies among HCV-infected patients not infected by routes other than drug injection need to be developed in order to disentangle the impact of drug use on anger's dimensions.

Conclusion. Findings indicate that routine psychosocial assessment of patient's pattern of symptoms should be integrated into HCV and HIV services in order to develop programs to reduce anger expression and to increase anger control ability. Indeed, anger behaviors can potentially be changed using group therapy (27). Our results need to be taken into account when individualising treatment strategy in co-infected patients in order to minimise possible side effects and optimize patient's clinical outcomes and quality of life. 


\section{References}

1. Palella FJ, Jr., Delaney KM, Moorman AC, Loveless MO, Fuhrer J, Satten GA, et al. Declining morbidity and mortality among patients with advanced human immunodeficiency virus infection. HIV Outpatient Study Investigators. N Engl J Med. 1998 Mar 26;338(13):853-60.

2. Tedaldi EM, Baker RK, Moorman AC, Alzola CF, Furhrer J, McCabe RE, et al. Influence of coinfection with hepatitis $\mathrm{C}$ virus on morbidity and mortality due to human immunodeficiency virus infection in the era of highly active antiretroviral therapy. Clin Infect Dis. 2003 Feb 1;36(3):363-7.

3. HIV/HCV coinfection cases require special attention. Experts discuss current treatments, concerns. AIDS Alert. 2004;19(10):109, 11-3.

4. Sherman KE, Rouster SD, Chung RT, Rajicic N. Hepatitis C Virus prevalence among patients infected with Human Immunodeficiency Virus: a cross-sectional analysis of the US adult AIDS Clinical Trials Group. Clin Infect Dis. 2002 Mar 15;34(6):831-7.

5. Sulkowski MS, Thomas DL. Perspectives on HIV/hepatitis C virus co-infection, illicit drug use and mental illness. Aids. 2005 Oct;19 Suppl 3:S8-12.

6. Piroth L, Duong M, Quantin C, Abrahamowicz M, Michardiere R, Aho LS, et al. Does hepatitis $\mathrm{C}$ virus co-infection accelerate clinical and immunological evolution of HIV-infected patients? Aids. 1998 Mar 5;12(4):381-8.

7. Greub G, Ledergerber B, Battegay M, Grob P, Perrin L, Furrer H, et al. Clinical progression, survival, and immune recovery during antiretroviral therapy in patients with HIV-1 and hepatitis C virus coinfection: the Swiss HIV Cohort Study. Lancet. 2000 Nov 25;356(9244):1800-5.

8. Sanchez-Quijano A, Andreu J, Gavilan F, Luque F, Abad MA, Soto B, et al. Influence of human immunodeficiency virus type 1 infection on the natural course of chronic parenterally acquired hepatitis C. Eur J Clin Microbiol Infect Dis. 1995 Nov;14(11):949-53.

9. Soto B, Sanchez-Quijano A, Rodrigo L, del Olmo JA, Garcia-Bengoechea M, Hernandez-Quero J, et al. Human immunodeficiency virus infection modifies the natural history of chronic parenterally-acquired hepatitis $\mathrm{C}$ with an unusually rapid progression to cirrhosis. J Hepatol. 1997 Jan;26(1):1-5.

10. Kramer L, Hofer H, Bauer E, Funk G, Formann E, Steindl-Munda P, et al. Relative impact of fatigue and subclinical cognitive brain dysfunction on health-related quality of life in chronic hepatitis C infection. Aids. 2005 Oct;19 Suppl 3:S85-92.

11. Soriano V, Puoti M, Sulkowski M, Mauss S, Cacoub P, Cargnel A, et al. Care of patients with hepatitis C and HIV co-infection. Aids. 2004 Jan 2;18(1):1-12.

12. Constant A, Castera L, Dantzer R, Couzigou P, de Ledinghen V, Demotes-Mainard J, et al. Mood alterations during interferon-alfa therapy in patients with chronic hepatitis $\mathrm{C}$ : evidence for an overlap between manic/hypomanic and depressive symptoms. J Clin Psychiatry. 2005 Aug;66(8):1050-7.

13. Kraus MR, Schafer A, Faller H, Csef H, Scheurlen M. Psychiatric symptoms in patients with chronic hepatitis $\mathrm{C}$ receiving interferon alfa-2b therapy. J Clin Psychiatry. 2003 Jun;64(6):708-14.

14. Raison CL, Borisov AS, Broadwell SD, Capuron L, Woolwine BJ, Jacobson IM, et al. Depression during pegylated interferon-alpha plus ribavirin therapy: prevalence and prediction. J Clin Psychiatry. 2005 Jan;66(1):41-8.

15. Nesic Z, Delic D, Prostran M, Stojanovic R, Vuckovic S, Todorovic Z. [Psychiatric adverse effects induced by recombinant interferon alfa in patients with chronic hepatitis $C]$. Med Pregl. 2004 May-Jun;57(5-6):219-26. 
16. Leserman J, Petitto JM, Gu H, Gaynes BN, Barroso J, Golden RN, et al. Progression to AIDS, a clinical AIDS condition and mortality: psychosocial and physiological predictors. Psychol Med. 2002 Aug;32(6):1059-73.

17. Singh N, Squier C, Sivek C, Wagener MM, Yu VL. Psychological stress and depression in older patients with intravenous drug use and human immunodeficiency virus infection: implications for intervention. Int J STD AIDS. 1997 Apr;8(4):251-5.

18. WHOQOL-HIV for quality of life assessment among people living with HIV and AIDS: results from the field test. AIDS Care. 2004 Oct;16(7):882-9.

19. Spielberger CD. Manual for the State-Trait Anger Expression Inventory, STAXI-2. Odessa, FL: Psychological Assessment Resources, Inc; 1999.

20. Obhrai J, Hall Y, Anand BS. Assessment of fatigue and psychologic disturbances in patients with hepatitis C virus infection. J Clin Gastroenterol. 2001 May-Jun;32(5):413-7.

21. Kraus MR, Schafer A, Csef H, Faller H, Mork H, Scheurlen M. Compliance with therapy in patients with chronic hepatitis C: associations with psychiatric symptoms, interpersonal problems, and mode of acquisition. Dig Dis Sci. 2001 Oct;46(10):2060-5.

22. Preau M, Leport C, Salmon-Ceron D, Carrieri P, Portier H, Chene G, et al. Healthrelated quality of life and patient-provider relationships in HIV-infected patients during the first three years after starting PI-containing antiretroviral treatment. AIDS Care. 2004 Jul;16(5):649-61.

23. Chander G, Himelhoch S, Moore RD. Substance Abuse and Psychiatric Disorders in HIV-Positive Patients : Epidemiology and Impact on Antiretroviral Therapy. Drugs. 2006;66(6):769-89.

24. De Moja CA, Spielberger CD. Anger and drug addiction. Psychol Rep. 1997 Aug;81(1):152-4.

25. Vogl D, Rosenfeld B, Breitbart W, Thaler H, Passik S, McDonald M, et al. Symptom prevalence, characteristics, and distress in AIDS outpatients. J Pain Symptom Manage. 1999 Oct;18(4):253-62.

26. Breitbart W, Rosenfeld B, Passik S, Kaim M, Funesti-Esch J, Stein K. A comparison of pain report and adequacy of analgesic therapy in ambulatory AIDS patients with and without a history of substance abuse. Pain. 1997 Aug;72(1-2):235-43.

27. Chan HY, Lu RB, Tseng CL, Chous KR. Effectiveness of the anger-control program in reducing anger expression in patients with schizophrenia. Arch Psychiatr Nurs. 2003 Apr;17(2):88-95. 
Table 1 - Socio-demographic, behavioral and clinical characteristics of $\mathrm{HIV} / \mathrm{HCV}$ coinfected patients receiving antiretroviral therapy - comparison of those patients treated and those not treated for $\mathrm{HCV}$ infection $(\mathrm{n}=139$, cross-sectional survey on HIV/HCV coinfected patients' QOL, France, 2005)

\begin{tabular}{|c|c|c|c|c|}
\hline Number of patients $(\%)$ & $\begin{array}{c}\text { All patients } \\
n=139 \\
\end{array}$ & $\begin{array}{c}\text { Patients treated } \\
\text { for } \mathbf{H C V} \text { infection } \\
\mathrm{n}=24\end{array}$ & $\begin{array}{c}\text { Patients not treated } \\
\text { for } \mathrm{HCV} \text { infection } \\
\mathrm{n}=115 \\
\end{array}$ & P-value ${ }^{1}$ \\
\hline Male gender & $89(64.0 \%)$ & 13 & 76 & 0.35 \\
\hline Mean age (SD) - years & $42.9(5.4)$ & $43.6(5.4)$ & $42.7(5.5)$ & 0.73 \\
\hline Mean time since HIV diagnosis (SD) - years & $15.5(4.4)$ & $15.9(3.4)$ & $15.5(4.6)$ & 0.97 \\
\hline \multicolumn{5}{|l|}{ HIV infection transmission category } \\
\hline - sexual contact & $24(17.3 \%)$ & 2 & 22 & \multirow[t]{3}{*}{0.49} \\
\hline - intravenous drug use & $113(81.3 \%)$ & 22 & 91 & \\
\hline - other & $2(1.4 \%)$ & 0 & 2 & \\
\hline $\begin{array}{l}\text { Mean HIV viral load (SD) - } \log _{10} \text { copies } / \mathrm{ml} \\
\text { CD4 count }- \text { cells } / \mathrm{mm}^{3}\end{array}$ & $2.26(1.06)$ & $1.89(0.70)$ & $2.34(1.11)$ & 0.23 \\
\hline - below 350 & $54(39.7 \%)$ & 13 & 41 & \multirow[t]{3}{*}{0.14} \\
\hline - between 350 and 500 & $31(22.8 \%)$ & 6 & 25 & \\
\hline - above 500 & $51(37.5 \%)$ & 5 & 46 & \\
\hline Mean duration of HIV treatment (SD) - years & $9.4(3.8)$ & $10.6(2.7)$ & $9.1(4.0)$ & 0.09 \\
\hline Mean time since $\mathrm{HCV}$ diagnosis (SD) - years & $10.9(5.4)$ & $11.6(4.8)$ & $10.7(5.6)$ & 0.43 \\
\hline \multicolumn{5}{|l|}{ HCV infection transmission category } \\
\hline - sexual contact & $25(18.0 \%)$ & 2 & 23 & \multirow[t]{3}{*}{0.44} \\
\hline - intravenous drug use & $102(73.4 \%)$ & 20 & 82 & \\
\hline - other & $12(8.6 \%)$ & 2 & 10 & \\
\hline \multicolumn{5}{|l|}{ Fibrosis stage $^{2}$} \\
\hline-0 to 1 & $29(37.7 \%)$ & 7 & 22 & \multirow{2}{*}{1.00} \\
\hline-2 to 4 & $48(62.3 \%)$ & 11 & 37 & \\
\hline \multicolumn{5}{|l|}{$\begin{array}{l}\text { Alcohol consumption } \\
\text { during the previous six months }\end{array}$} \\
\hline - less than two times a week & $111(79.9 \%)$ & 23 & 88 & \multirow[t]{2}{*}{0.05} \\
\hline - at least two times a week & $28(20.1 \%)$ & 1 & 27 & \\
\hline \multicolumn{5}{|l|}{ Number of glasses consumed per day } \\
\hline - less than 3 ( 2 for women $)$ & $107(79.3 \%)$ & 21 & 86 & \multirow[t]{2}{*}{0.16} \\
\hline - at least 3 (2 for women) & $28(20.7 \%)$ & 2 & 26 & \\
\hline \multicolumn{5}{|l|}{$\begin{array}{l}\text { Drug use } e^{3} \text { during the previous four weeks - } \\
n=121\end{array}$} \\
\hline - none & $95(78.5 \%)$ & 14 & 81 & \multirow[t]{2}{*}{0.08} \\
\hline - at least one & $26(21.5 \%)$ & 8 & 18 & \\
\hline $\begin{array}{l}\text { Depression global score (CES-D) } \\
\text { median [IQR] }\end{array}$ & $18[11 ; 27]$ & $20[14 ; 27]$ & $18[11 ; 27]$ & 0.22 \\
\hline
\end{tabular}

$\mathrm{SD}=$ standard deviation; IQR = interquartile range

${ }^{1}$ comparison of those patients treated and those not treated for HCV infection (Fisher's exact test for categorical variables, Wilcoxon rank-sum test for continuous variables)

${ }^{2}$ data on fibrosis stage (biopsy results or FibroTest ${ }^{\mathrm{TM}}$ score) are available for half of the patients

${ }^{3}$ Use of at least one of the following products: cannabis, cocaine, heroin, crack, ecstasy, amphetamins, buprenorphine without medical prescription, LSD or other hallucinogens 
Table 2 - State-Trait Anger Expression Inventory-2 (STAXI-2) scores in HIV/HCV coinfected patients receiving antiretroviral therapy: comparison of those patients treated and those not treated for $\mathrm{HCV}$ infection $(n=139$, cross-sectional feasibility survey for the HEPAVIH project, 2005, French National Agency for AIDS and viral hepatitis Research - ANRS)

\begin{tabular}{lccc}
\hline $\begin{array}{l}\text { median } \\
\text { interquartile range }]\end{array}$ & $\begin{array}{c}\text { Patients treated } \\
\text { for HCV infection } \\
\mathrm{n}=24\end{array}$ & $\begin{array}{c}\text { Patients not treated } \\
\text { for HCV infection } \\
\mathrm{n}=115\end{array}$ & P-value $^{1}$ \\
\hline $\begin{array}{l}\text { State Anger } \\
\mathrm{n}=107\end{array}$ & $22[15 ; 30]$ & $17[15 ; 21]$ & 0.07 \\
Trait Anger & & $17[14 ; 21]$ & 0.27 \\
$\mathrm{n}=109$ & $20.5[13 ; 23.5]$ & $14[13 ; 17]$ & 0.78 \\
$\begin{array}{l}\text { Anger Expression-Out } \\
\mathrm{n}=108\end{array}$ & $16[11 ; 18]$ & $18[15 ; 21]$ & 0.83 \\
$\begin{array}{l}\text { Anger Expression-In } \\
\mathrm{n}=109\end{array}$ & $18[14.5 ; 21]$ & $23[18 ; 26]$ & 0.02 \\
$\begin{array}{l}\text { Anger Control-Out } \\
\mathrm{n}=110\end{array}$ & $18.5[17.5 ; 23]$ & $22[17.5 ; 25]$ & 0.47 \\
$\begin{array}{l}\text { Anger Control-In } \\
\mathrm{n}=103\end{array}$ & $20[18 ; 23]$ & & \\
\hline
\end{tabular}

${ }^{1}$ nonparametric two-sided Wilcoxon rank-sum test 